
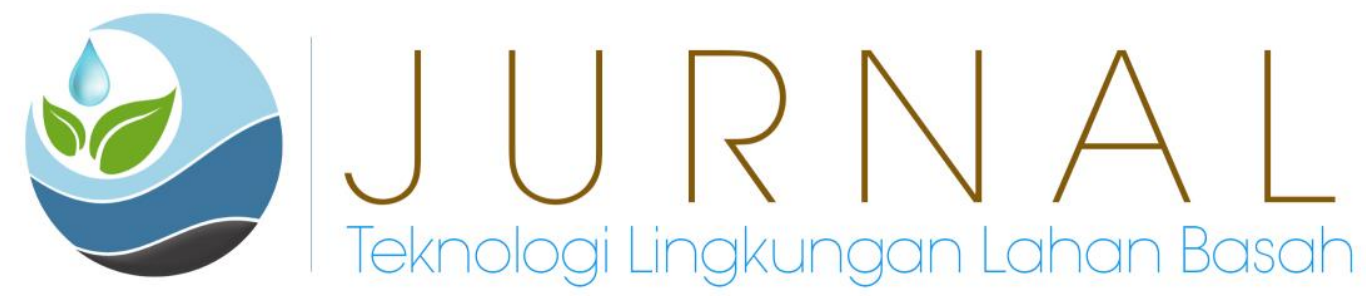

\title{
Aplikasi Biosurfaktan Bacillus Subtilis ATCC 19659 dengan Media Produksi Limbah Tahu untuk Enhaced Oil Recovery
}

\author{
Rizqy Fachria \\ Jurusan Teknik Lingkungan Universitas Nahdlatul Ulama \\ E-mail : rizqy.fachria@gmail.com
}

\begin{abstract}
Biosurfactant as secondary metabolit produced by Bacillus subtilis. It has the ability to emulsify and reduce the surface tension. Biosurfactants produced by B. subtilis is a lipopeptide. Furthermore, biosurfactant can be utilized in microbial enhanced oil recovery (MEOR). In this research, biosurfactant of B. subtilis ATCC 19659 were evaluated. The production use Nutrient Broth (NB) and soybean liquid waste. Application of biosurfactant in oil recovery showed that biosurfactant of NB recover $2 \mathrm{~mL}$ crude oil and biosurfactant of soybean liquid waste medium recover $3.67 \mathrm{~mL}$.
\end{abstract}

Keywords: application test, Bacillus subtilis, biosurfactant,

\begin{abstract}
Abstrak
Biosurfaktan merupakan metabolit sekunder yang diproduksi oleh Bacillus subtilis. Biosurfaktan memiliki kemampuan emulsifikasi dan menurunkan tegangan permukaan. Biosurfaktan yang diproduksi oleh B.subtilis adalah lipopeptida. Oleh karena itu, biosurfaktan dapat digunakan pada microbial enhaced oil recovery (MEOR). Pada penelitian ini, biosurfaktan dari B.subtilis ATCC 19659 diuji. Produksi biosurfaktan menggunakan Nutrient Broth (NB) dan limbah cair tahu. Berdasar uji aplikasi biosurfaktan mengeluarkan minyak mentah dari pasir, biosurfaktan dari media NB dapat mengeluarkan $2 \mathrm{~mL}$, sedangkan biosurfaktan dari media limbah cair tahu dapat mengeluarkan $3.67 \mathrm{~mL}$.
\end{abstract}

Kata Kunci: Bacillus subtilis, biosurfaktan, uji aplikasi

\section{PENDAHULUAN}

Produksi minyak bumi di Indonesia mulai menurun sejak tahun 1995. Produksi hanya dapat ditingkatkan melalui penemuan sumur produksi baru atau aplikasi teknologi enhanced oil recovery (EOR) di sumur tua. EOR merupakan teknik recovery minyak yang masih tersisa setelah pengurasan primer dan sekunder (Tunio et al., 2011). Menurut data cadangan minyak dan gas bumi yang dikelola LEMIGAS terdapat $62 \%$ dari isi awal minyak yang tertinggal dalam reservoar setelah proses pengurasan primer dan sekunder. Hal ini mendorong teknologi EOR untuk dikembangkan. Metode EOR yang telah dikenal saat ini adalah metode injeksi kimia, injeksi gas tercampur, metode termal dan microbial enhanced oil recovery (MEOR) (Usman, 2011). Metode ini memerlukan energi tinggi dan biaya yang mahal serta dapat mencemari lingkungan.

Berbeda dengan metode EOR lainnya, MEOR merupakan metode yang murah dan ramah lingkungan. MEOR adalah teknik EOR yang menggunakan bakteri atau produk 
metabolit dari bakteri dalam proses mobilisasi minyak bumi dalam reservoar (Rashedi et al., 2012). Bakteri dan nutrisi yang diinjeksikan mudah didapatkan dan tidak memerlukan perlakuan khusus, sehingga dapat mengurangi biaya produksi. Selain itu, proses MEOR dapat diaplikasikan pada reservoar carbonate-oil, dimana teknologi EOR lainnya tidak efisien untuk digunakan. Terakhir, produk MEOR dapat terdegradasi dan tidak terakumulasi di lingkungan (Lazar et al., 2007).

Salah satu produk bakteri yang dapat digunakan dalam MEOR adalah biosurfaktan. Biosurfaktan merupakan salah satu molekul amfipatik dari nabati maupun bakteri yang memiliki bagian polar (hidrofilik) dan nonpolar (lipofilik) (Dhail, 2013). Kedua bagian tersebut berperan dalam menurukan tegangan permukaan dan meningkatkan sifat kebasahan (Lazar et al.,2007). Bagian polar dapat berupa karbohidrat, asam amino dan fosfat, sedangkan nonpolar dapat berupa asam lemak beserta turunannya. Biosurfaktan dikategorikan berdasarkan komponen penyusunnya, yaitu glikolipid, lipopeptida, lipid alami, fosfolipid, partikulat biosurfaktan dan polimer biosurfaktan (Nitschke \& Coast, 2007).

Biosurfaktan pada penelitian ini akan diproduksi oleh bakteri Bacillus subtilis ATCC 19659. Genus Bacillus biasanya menghasilkan biosurfaktan jenis lipopeptida, bernama surfaktin. Surfaktin merupakan jenis biosurfaktan yang paling efektif dalam menurunkan tegangan permukaan (Vijayakumar \& Saravanan, 2015). Selain itu, surfaktin dapat bertahan pada suhu, $\mathrm{pH}$, dan salinitas ekstrim serta dapat diproduksi menggunakan media limbah (Pacwa-Plociniczak et al., 2011). Pada penelitian ini digunakan media produksi dari limbah cair tahu untuk mengurangi biaya produksi. Limbah cair tahu memiliki kandungan karbohidrat dan protein yang menjadi sumber nutrisi bagi bakteri ( $\mathrm{Li}$ et al,. 2013). Penggunaan limbah cair tahu sebagai media produksi dapat menjadi salah satu cara mengurangi pencemaran lingkungan (Muliawati, 2006).

Penelitian ini bertujuan untuk menguji aplikasi biosurfaktan untuk mengeluarkan minyak dari pasir. Biosurfaktan hasil B. subtilis ATCC 19659 diharapkan mampu diaplikasikan dalam proses recovery minyak. Hasil penelitian ini dapat digunakan sebagai salah satu acuan untuk pengujian MEOR dengan $B$. subtilis menggunakan media tahu di lapangan.

\section{METODE PENELITIAN}

\section{A. Bahan dan Alat}

Peralatan yang digunakan untuk produksi biosurfaktan adalah erlenmeyer $1 \mathrm{~L}$, gelas ukur, pipet mohr, mikropipet, pH-meter, autoklaf dan inkubator bergoyang. Ekstraksi biosurfaktan menggunakan Sentrifus Beckman J21, corong pisah $500 \mathrm{~mL}$, rotary evaporator dan inkubator.

Bahan utama dalam penelitian adalah biakan bakteri B. subtilis ATCC 19659. Media produksi biosurfaktan menggunakan media nutrient broth (NB) dan limbah cair tahu dari pabrik tahu Cibeureum, Bogor, Jawa Barat. Pengaturan $\mathrm{pH}$ menggunakan $\mathrm{HCl} 6 \mathrm{M}$ dan $\mathrm{NaOH} 4 \mathrm{M}$. Pelarut kloroform dan metanol digunakan untuk ekstraksi biosurfaktan. Terakhir, minyak mentah asal Bojonegoro, Jawa Timur, pasir pantai dari Pantai Ancol, akuades sebagai kontrol negatif dan SDS 1\% sebagai kontrol positif digunakan dalam uji aplikasi biosurfaktan. 


\section{B. Prosedur}

\section{Produksi Biosurfaktan dari B. Subtilis}

Penyiapan media kultur. Media tumbuh yang digunakan adalah limbah cair tahu dan media NB. Limbah cair tahu 1 L yang berasal dari pabrik tahu Cibereum disaring menggunakan kertas saring. Media NB dibuat dengan konsentrasi $5 \%$ sebanyak $1 \mathrm{~L}$. Kedua media diatur $\mathrm{pH}$-nya menjadi 7.2 menggunakan $\mathrm{NaOH} 4 \mathrm{M}$ dan $\mathrm{HCl} 6 \mathrm{M}$. Media yang telah sesuai $\mathrm{pH}$-nya disterilisasi menggunakan autoklaf pada suhu $121{ }^{\circ} \mathrm{C}$ selama 15 menit (Waghmode et al., 2014).

Produksi biosurfaktan. Proses produksi diawali dengan pembuatan starter dengan menumbuhkan B. subtilis ATCC 19659 selama 24 jam dalam media NB. Sebanyak $2.5 \mathrm{~mL}$ starter dipindahkan ke media limbah cair tahu $250 \mathrm{~mL}$ dan media NB $250 \mathrm{~mL}$ pada gelas erlenmeyer $1 \mathrm{~L}$. Setelah itu, diinkubasi pada suhu ruang dengan kecepatan 100 rpm selama 96 jam untuk media limbah cair tahu, sedangkan media NB diinkubasi selama 72 jam.

\section{Ekstraksi Biosurfaktan}

Media produksi disentrifus dengan kecepatan $4000 \mathrm{rpm}$ selama 20 menit. Supernatan yang diperoleh adalah sumber biosurfaktan kasar. Supernatan tersebut diasamkan hingga $\mathrm{pH}$-nya menjadi 2 menggunakan $\mathrm{HCl} 6 \mathrm{M}$. Selanjutnya disimpan dalam lemari pendingin pada suhu $4{ }^{\circ} \mathrm{C}$ selama 24 jam untuk mengendapkan lipid dan protein. Larutan diekstraksi dengan kloroform dan metanol $(2: 1 \mathrm{v} / \mathrm{v})$ menggunakan corong pisah. Ekstrasi dilakukan sebanyak $3 \mathrm{kali}$ untuk mendapatkan ekstrak biosurfaktan. Hasil ekstraksi dipekatkan menggunakan rotatory evaporator suhu $50{ }^{\circ} \mathrm{C}$ dengan kecepatan. Terakhir biosurfaktan ditimbang menggunakan timbangan analitik (Winajarko et al. 2012).

\section{Uji Aplikasi Biosurfaktan Mengeluarkan Minyak Mentah dalam Pasir}

Uji aplikasi biosurfaktan dilakukan menggunakan pasir yang dicampur minyak mentah. Sebanyak $50 \mathrm{~g}$ pasir dicampur dengan $5 \mathrm{~g}$ minyak mentah dalam erlenmeyer $250 \mathrm{~mL}$ lalu diinkubasi dengan inkubator bergoyang selama 24 jam dengan kecepatan $100 \mathrm{rpm}$. Setelah itu, ditambahkan $50 \mathrm{~mL}$ sampel biosurfaktan dari media NB dan limbah cair tahu, SDS $1 \%$ sebagai control positif dan akuades sebagai kontrol negatif. Inkubasi dilakukan kembali selama 24 jam. Minyak yang berada di permukaan dipisahkan dan dihitung volumenya. Pengujian ini diulang sebanyak tiga kali (Periera et al. 2013).

\section{HASIL DAN PEMBAHASAN}

\section{A. Hasil}

\section{Ekstrak Biosurfaktan dari B.subtilis}

Ekstraksi dilakukan menggunakan corong pisah dengan pelarut kloroform : metanol $(2: 1 \mathrm{v} / \mathrm{v})$. Biosurfaktan yang dapat diekstraksi dari media NB dan media limbah tahu dengan volume $1 \mathrm{~L}$ ditunjukkan pada Tabel 1. Massa biosurfaktan dari media NB lebih banyak dibandingkan massa biosurfaktan dari media limbah cair tahu.

Tabel 1. Ekstrak biosurfaktan dari B. subtilis ATCC 19659

\begin{tabular}{|l|c|}
\hline \multicolumn{1}{|c|}{ Sampel } & Massa (gram) \\
\hline Biosurfaktan media NB & 0.8705 \\
Biosurfaktan media limbah cair tahu & 0.0470 \\
\hline
\end{tabular}

Sumber: data primer penelitian 
Biosurfaktan pada penelitian ini diproduksi dalam dua media, yaitu media NB dan media limbah tahu. Media NB menghasilkan biosurfaktan paling optimal setelah inkubasi selama 72 jam, sedangkan media limbah cair tahu perlu diinkubasi selama 96 jam. Pemisahan biosurfaktan dan biomassa sel bakteri dilakukan menggunakan sentrifus berpendingin. Menurut Maneerat \& Phetrong (2007), biosurfaktan merupakan produk metabolit sekunder ekstraseluler. Biosurfaktan berada pada bagian supernatan, sedangkan biomassa sel bakteri berada di pelet. Supernatan yang didapat merupakan ekstrak biosurfaktan kasar yang selanjutnya diekstraksi dan menjadi bahan untuk uji aplikasi. Sebelum diekstraksi, biosurfaktan kasar diasamkan dan didinginkan selama 24 jam untuk mengendapkan protein dan lipidnya. Metode ekstraksi cair-cair digunakan untuk mendapatkan biosurfaktan.

Ekstraksi cair-cair merupakan pemisahan senyawa kimia diantara dua fase pelarut yang tidak saling bercampur. Berdasar penelitian Muliawati (2006), biosurfaktan memiliki sifat semipolar dan lebih mengarah ke polar sehingga pelarut yang digunakan adalah kloroform:metanol (2:1). Ekstraksi dilakukan sebanyak 3 kali untuk menghilangkan senyawa pengotornya. Metode ekstraksi ini efektif dan tidak membutuhkan biaya yang besar, namun membutuhkan pelarut yang banyak. Terakhir, ekstrak dipekatkan menggunakan rotary evaporator. Massa biosurfaktan dari media NB, $0.8705 \mathrm{~g}$ lebih banyak dibandingkan massa biosurfaktan yang didapat dari media limbah cair tahu, $0.0470 \mathrm{~g}$. Hal ini dapat disebabkan kandungan media NB, yaitu pepton dan ekstrak ragi. Pepton dan ekstrak ragi dapat larut dalam kloroform:metanol, sehingga massa biosurfaktan dari media NB lebih banyak dibandingkan biosurfaktan dari media limbah cair tahu (Muliawati, 2006).

\section{Aplikasi Biosurfaktan Mengeluarkan Minyak Mentah dalam Pasir}

Uji aplikasi dilakukan menggunakan ekstrak kasar biosurfaktan dari media NB dan media limbah cair tahu. Ekstrak kasar biosurfaktan diuji untuk mengeluarkan minyak mentah dari pasir. Parameter yang digunakan adalah volume yang berhasil terangkat dari pasir oleh biosurfaktan. Kontrol negatif yang digunakan adalah akuades, sedangkan SDS $1 \%$ digunakan sebagai kontrol positif. Hasil uji aplikasi biosurfaktan dapat dilihat pada Tabel 2. Volume minyak yang dapat terangkat oleh air hanya $0.3 \mathrm{~mL}$, kemudian biosurfaktan media NB dan media limbah cair tahu secara berurutan dapat mengangkat $2 \mathrm{~mL}$ dan $3.67 \mathrm{~mL}$ minyak. Terakhir, SDS 1\% mampu mengangkat minyak dengan volume $4.67 \mathrm{~mL}$. Penampakan minyak yang terangkat oleh masing-masing sampel terlihat pada Gambar 1.

Tabel 2. Volume minyak yang terangkat dari pasir oleh sampel

\begin{tabular}{|c|l|c|c|}
\hline No & \multicolumn{1}{|c|}{ Sampel } & $\begin{array}{c}\text { Volume minyak } \\
(\mathrm{mL})\end{array}$ & \% Minyak \\
\hline 1 & Air akuades & 0.3 & 4.6 \\
2 & Biosurfaktan media NB & 2 & 30 \\
3 & Biosurfaktan media limbah air tahu & 3.67 & 56 \\
4 & SDS 1 \% & 4.67 & 71 \\
\hline
\end{tabular}

Sumber: data primer penelitian 
[a]

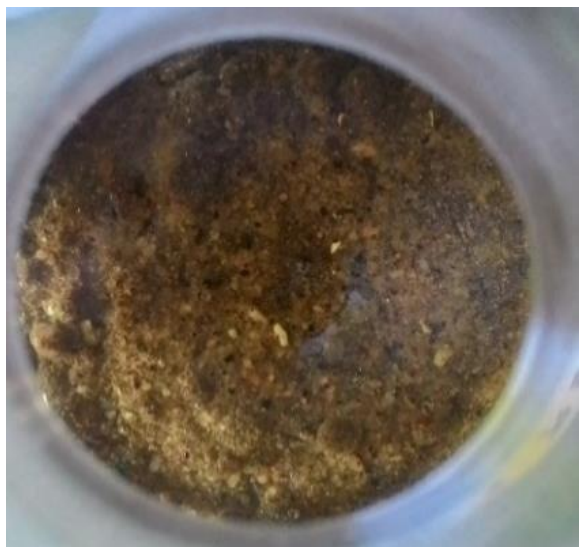

[c]

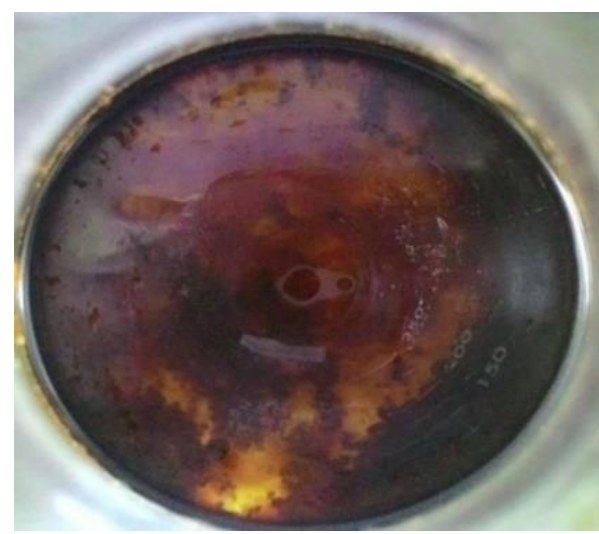

[b]

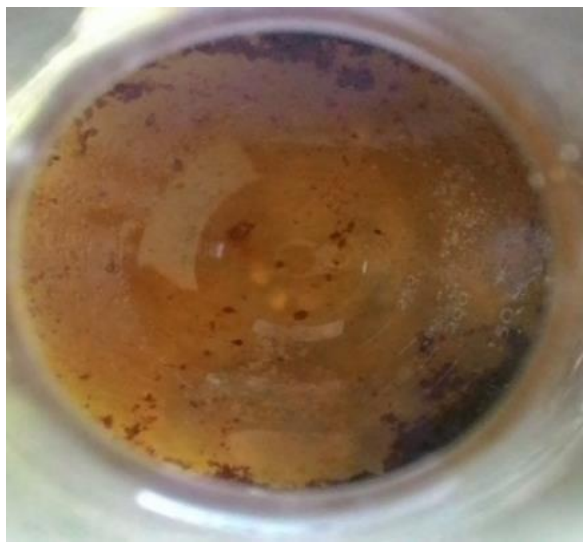

[d]

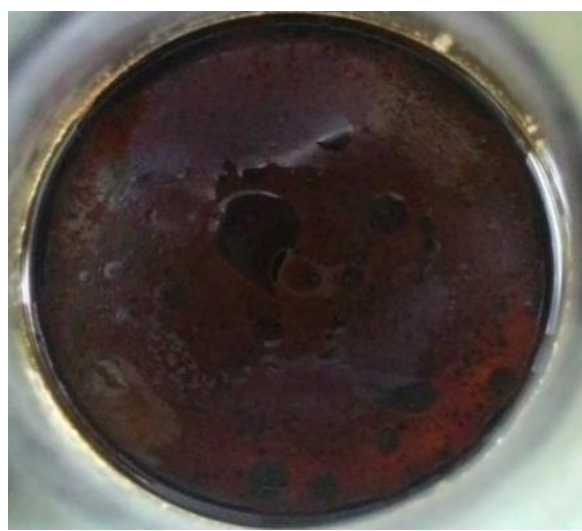

Keterangan : (a) air (b) biosurfaktan media NB (c) biosurfaktan media tahu (d) SDS 1\%

Gambar 1. Minyak mentah yang dapat terangkat oleh sampel

Sumber: data primer penelitian

Salah satu aplikasi biosurfaktan adalah MEOR. Metode MEOR digunakan untuk mengambil minyak yang tertinggal dalam reservoar setelah proses recovery primer dan sekunder. Minyak tersebut sulit diambil karena terjerap dalam poripori. MEOR menggunakan mikroorganisme beserta produknya, seperti biosurfaktan, biopolimer, biomassa, asam, dan enzim dalam proses pengambilan minyak bumi. Biosurfaktan bekerja dengan mengurangi tegangan permukaan antara minyak/air dan minyak/batu, sehingga mencegah minyak masuk dalam pori-pori (Pacwa-Plociniczak 2011).

Uji aplikasi biosurfaktan skala laboratorium dapat dilakukan dengan mengeluarkan minyak mentah dalam pasir. Biosurfaktan dari media NB dan limbah cair tahu diuji kemampuannya untuk mengeluarkan minyak dalam pasir. Hasilnya dibandingkan dengan kontrol negatif berupa air akuades dan kontrol positif berupa SDS $1 \%$. Tabel 2 menunjukkan volume minyak yang dapat terangkat oleh tiap sampel. Semakin banyak volume yang terangkat semakin baik kerja dari biosurfaktan. Air sebagai kontrol negatif dapat mengangkat $0.3 \mathrm{~mL}$ minyak mentah, karena proses pengocokan membantu minyak yang terjerap dalam pasir sedikit demi sedikit terangkat ke permukaan air.

Biosurfaktan dari media NB dan media limbah cair tahu dapat mengeluarkan minyak mentah dengan baik. Biosurfaktan dari media limbah cair tahu lebih 
efektif dalam mengeluarkan minyak mentah dibandingkan biosurfaktan dari media NB. Hal ini dapat disebabkan kandungan oktadekanol pada ekstrak biosurfaktan dari media tahu memiliki kemampuan menurunkan tegangan permukaan lebih efektif dibandingkan asam oktadekenoat yang terdapat pada biosurfaktan media NB (Jiang et al., 2012). Selain itu, dalam media limbah cair tahu terdapat zat pengemulsi dari sisa pembuatan tahu, yaitu lesitin, sehingga dapat membantu proses pengangkatan minyak mentah dari pasir (Li et al., 2013). Terakhir, larutan SDS 1\% memiliki volume minyak terangkat yang paling banyak.

Biosurfaktan dan SDS 1\% dapat mengeluarkan minyak mentah dari pasir karena memiliki sifat pengemulsi dan menurunkan tegangan permukaan. Molekul biosurfaktan membentuk agregat globular (misel) dengan bagian hidrofiliknya yang menghadap ke air dan lipofiliknya yang berikatan dengan minyak di bagian tengah. Pembentukan misel memudahkan minyak keluar dari pori-pori pasir (Hart et al., 2003).

\section{PENUTUP}

\section{A. Simpulan}

Biosurfaktan hasil ekstraksi dari media NB (0.8705 gram) lebih banyak dibandingkan biosurfaktan dari media limbah cair tahu (0.0470 gram), namun ekstrak biosurfaktan dari media limbah tahu lebih efektif dalam mengeluarkan minyak mentah dari pasir. Hal ini disebabkan senyawa yang terkandung didalamnya.

\section{B. Saran}

Perlu dilakukan penelitian ke skala lanjut terhadap aplikasi biosurfaktan untuk pengangkatan minyak. Sehingga didapat gambaran efektifitasnya di lapangan.

\section{DAFTAR PUSTAKA}

Dhail S. 2013. Microbial enhanced oil recovery using potent biosurfactant produced by Pseudomonas sp. From Arabian Sea, Mumbai. J Petrol Gas Engineer. 4(3): 57-60.

\section{Hart H, Craine LE, Hart DJ. 2003. Kimia Organik. Jakarta (ID) : Penerbit Erlangga}

Jiang J, Tong G, Chin YF. 2012. The effect of charge and chemical structure of cationic surfactants on laser toner agglomeration under alkaline pulping conditions. Bio Res. 7(2): 1684-1696.

Lazar I, Petrisor IG, Yen TF. 2007. Microbial enhanced oil recovery (MEOR). Petrol Sci Tech. 25(11): 1353-1366.

Li S, Zhu D, Li K, Yang Y, Lei Z, Zhang Z. 2013. Soybean Curd residue: composition, utilization, and related limiting factors. ISRN Industrial Engineering.

Maneerat S, Phetrong K. 2007. Isolation of biosurfactant-producing marine bacteria and characteristics of selected biosurfactant. Songklanakarin J Sci Tech. 29(3):781-791.

Muliawati DI. 2006. Sintesis biosurfaktan dengan menggunakan minyak kedelai sebagai sumber karbon tambahan secara biotransformasi oleh Pseudomonas aeruginosa [skripsi]. Surakarta (ID): Universitas Sebelas Maret Surakarta.

Nitschke M, Coast SG. 2007. Biosurfactants in food industry. Trends in Food Sci Tech. 18:252-259. 
Pacwa-Plociniczak M, Plaza GA, Piotrowska-Seget Z, Cameotra SS. 2011. Environmental applications of biosurfactants: recent advances. Int J Mol Sci 12: 633654.

Pereira JFB, Gudina EJ, Costa R, Vitorino R, Teixeira JA, Coutinho JAP et al.2013.Optimization and characterization of biosurfactant production by Bacillus subtilis isolates towards microbial enhanced oil recovery applications. Fuel.111: 259268.

Rashedi H, Yazdian F, Naghizadeh. 2012. Introduction to Enhanced Oil Recovery (EOR) Processes and Bioremediation of Oil-Contaminated Sites. China : InTech.

Usman. 2011. Potensi Pengembangan EOR untuk Peningkatan Produksi Minyak Indonesia. Lembaran Pub Minyak Gas Bumi. 45(2): 91-102.

Vijayakumar S, Saravanan V. 2015. Biosurfactants-type, sources, and applications. Res J Microbiol. 10(5): 181-192.

Waghmode S, Kulkarni C, Shukla S, Sursawant P, Velhal C. 2014. Low cost production of biosurfactant from different substrates and their comparative study with commercially available chemical surfactant. Inter J Sci Tech Res. 3(3): 146-149.

Winajarko A, Yuliani H, Hermansyah H, Sahlan M. 2012. Isolation and properties characterization of biosurfactant synthesized by pyrene degrading Bacillus subtilis C19. J Chem Chem Eng. 6: 889 - 896. 